\title{
THE BIBANGA LEPER SETTLEMENT, BELGIAN CONGO
}

At the kind invitation of Dr. Kellersberger, I visited his station at Bibanga, Lusambo Province, Belgian Congo, on June 26th and inspected his anti-leprosy work during the three days I was there. The Leper Settlement is situated some three miles from the Mission Station on the edge of an escarpment looking down to the Lublilash valley. The patients are housed in neat square huts of sun-dried bricks and grass thatch. Each family has a separate hut with two rooms which are rather dark from lack of windows, but are well ventilated under the thatch. Each hut has a separate pit latrine 6 or 7 feet deep; they appear to be fairly sanitary, though they are open and breed flies to a certain extent. The huts are well spaced and are arranged in broad streets lined with rows of trees. It is proposed to place all open cases at the one end of the settlement and closed cases at the other end. At the time of my visit there were on the roll 205 men, 136 women, 57 boys and 30 girls, making a total of 428 . They all live in families and no attempt has so far been made to separate children from infectious parents. Several of the patients were absent on leave at their homes.

\section{Types of Cases}

I had an opportunity of inspecting 289 patients and discussing them with Dr. Kellersberger and his African assistants. I made a rough classification of these into five groups: (I) Severe lepromatous cases $\left(\mathrm{L}_{2}\right.$ and $\left.\mathrm{L}_{3}\right)$; (2) Mild or unadvanced lepromatous cases $\left(L_{1}\right)$; (3) Neural cases with tuberculoid lesions $\left(\mathrm{N}_{1}\right.$, $\mathrm{N}_{2}, \mathrm{~N}_{3}$ ); (4) Undetermined cases with flat lesions; (5) Cases without active signs. These groups were divided without bacteriological examination and the classification is, therefore, only a provisional one, probably the best possible in the short time available. Each group was sub-divided into cases with or without deformities and disablement, and was also divided into males and females.

Group

(I) Deformed Undeformed

(2) Deformed Undeformed

\section{Males}

o)

40) 40

5)

22) 27
Females

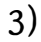

22) 25

4)

33) 37
Totals

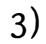

62) 65

55) 64 
Group

(3)

\begin{tabular}{|c|c|c|c|}
\hline Deformed & $\cdots$ & 5) & \\
\hline Undeformed & $\ldots$ & 35) & 40 \\
\hline Deformed & $\ldots$ & 4) & \\
\hline Undeformed & . & 9) & I3 \\
\hline Deformed & 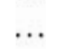 & 2) & \\
\hline Undeformed & $\ldots$ & 2I) & 23 \\
\hline
\end{tabular}

I43
Females

3)

6I) 64

2)

8) 10

I)

9) Io

I46
Totals

8)

96) 104

6)

I7) 23

3)

30) 33

The table shows several points of interest :-

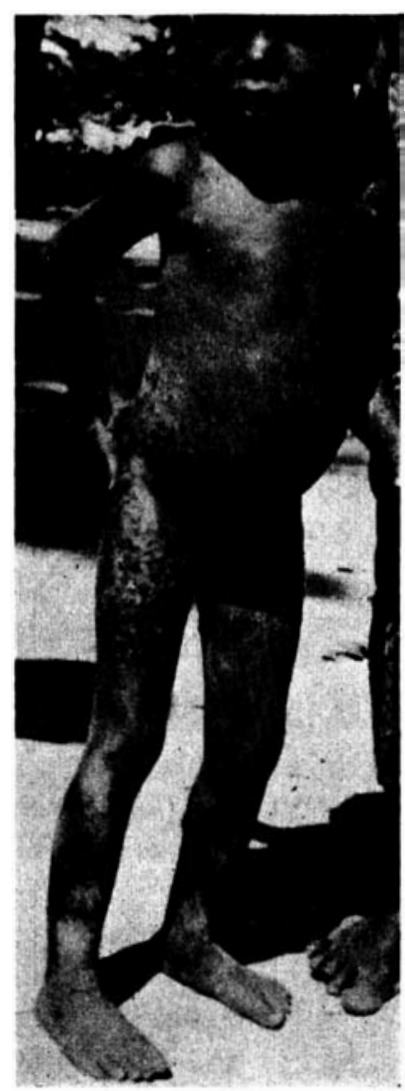

FIG. 3

Bibanga: leprosy in young child, accompanied by scabies, impetigo, malnutrition.
( I) The large proportion of lepromatous cases, just over 5o per cent of all those with active lesions. Only half of these might. be considered as serious infection spreaders. There were very few of the grosser forms of lepromatous case. No case of lepra reaction was found and I understand that this condition is very rare. Only 9.3 per cent of the lepromatous cases showed serious deformity or disablement, and the few trophic ulcers of the feet were chiefly slight and superficial.

(2) Forty per cent of the active cases had definite tuberculoid lesions, though none of these could be classed as "major." This is a large proportion, but corresponds with findings in the Stanleyville Province of Congo Belge (Leprosy Reviezu, January, 1939). Only 7.6 per cent of these had serious deformity or disablement.

(3) In thirty-three cases (II per cent) no active signs were found.

(.4) Comparing the males with the females, 33 per cent of the former and I 8 per cent of the latter were classed as serious lepromatous cases $\left(\mathrm{L}_{2}\right.$ and $\left.\mathrm{I}_{3}\right)$; among the women there were fewer and milder deformities, and the disease, as elsewhere, is of a definitely milder type among women than among men. There are fewer women than men on the roll.

Accompanying Diseases and Other Conditions. A large proportion of the patients were found to be suffering from scabies (fig. 3), and different forms of mycosis, complicated by septic infections. In some a condition resembling chronic pellagra and 
other forms of deficiency skin diseases were found. A few had septic eye complications and several had enlarged spleens and livers, suggesting malaria and bilharzia. The majority showed fairly good physique.

\section{SugGestions :}

(I) The patients with no active signs might be discharged, except, perhaps, some of those too disabled to earn their living.

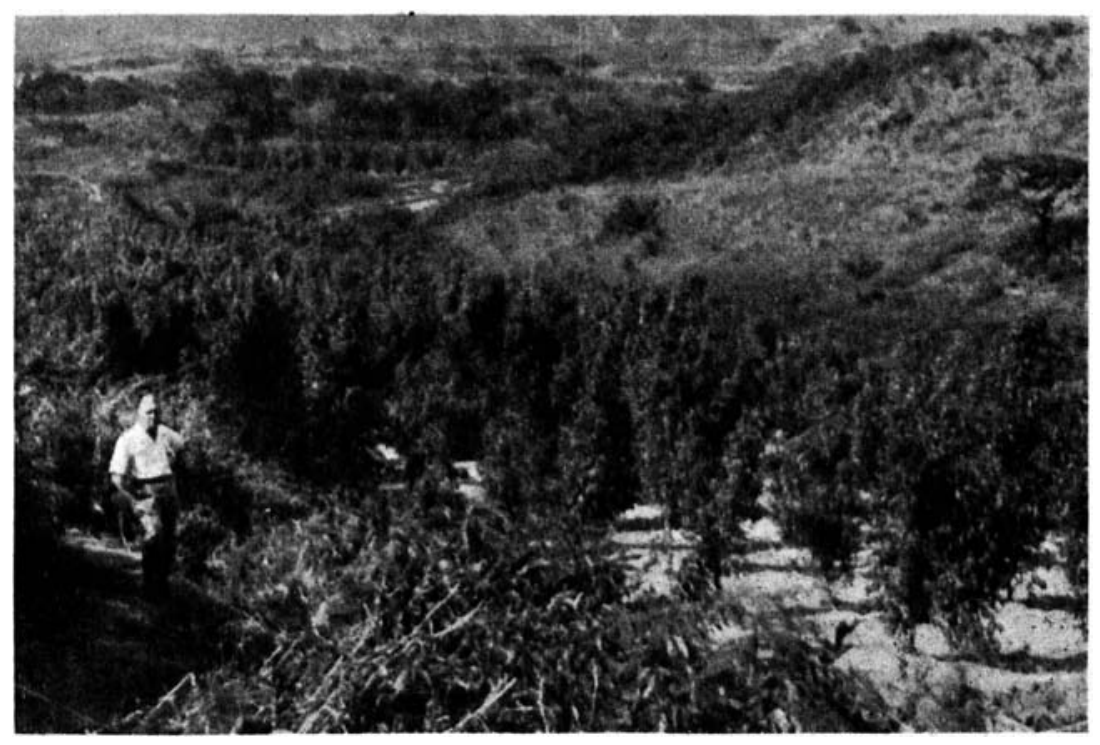

FIG. 4.

Plantation of Hydnocarpus anthelmintica trees at Bibango, Belgian Congo

(2) Many of the neural cases might be cleared up rapidly with intradermal injections and painting with caustics. The rapid clearing up of these would certainly popularise the treatment, and the discharge of many of these two groups would make room for other patients; and many non-leprous children dependent on them would be removed from the dangers of living in a leper settlement.

(3) Stress should be laid on clearing up complicating diseases, especially those of the skin. Care might be taken that patients wash thoroughly and daily with soap and plenty of water. Oil should be supplied to rub on the skin, and scabies and mycosis treated (Fig. 3).

(4) Strictness should be exercised to prevent unauthorized absence from the leper settlement. 
(5) Children of open cases should be separated from their infectious parents.

(6) Nourishing food, vitamins, etc., should be supplied to those in need of them.

It is fully realised that the settlement is badly handicapped for need of funds and closer supervision. A very fine piece of work is being done by Dr. Kellersberger, but it is only one of his many activities. Only about 7 francs per month per capita (2I cts. American money) is supplied by the Government, and this covers only a fraction of the amount required.

The patients build their own houses and support themselves to a large extent by their own agriculture, but the land available (only about 500 acres) is inadequate for the present number of patients. There should be a nursing sister in immediate charge, as there is in many of the settlements in Nyasaland and Northern Rhodesia.

Such essential supplies as soap and oil for rubbing on the skin are wanting for lack of money. It is impossible to run a leper settlement without adequate funds.

Hydnocarpus Plantation. An interesting feature is the plantation of Hydnocarpus anthelmintica trees from which excellent oil is obtained for treatment. This useful tree might be further cultivated with profit in other places (fig. 4).

General Conclusions. Bibanga is one of the few places in the Belgian Congo where leprosy is being effectively treated. In spite of all the disadvantages mentioned above, good results are being obtained, though I consider that without great difficulty better and more rapid results might be obtained in many cases.

Leprosy, as in the Stanleyville province, appears to be on the whole of a mild type, certainly considerably milder than that found in India, Burma and Malaya. Ordinary cleanliness of the people and the clearing up of skin diseases connected with dirt should, to a large extent, reduce the number of cases in this region, especially those of the neural type. The people at large appear to have high resistance to leprosy, even in spite of malnutrition and complicating diseases; but the infection is apparently broadcast by dirt, scratching and promiscuousness.

I would strongly recommend that the excellent work being done by Dr. Kellersberger should receive further support from Government, from the Mission and from others who are interested in helping sufferers from leprosy, and in controlling this widespread disease. 